\title{
Tracer Study of Alumni Profiles and STEI Contribution to the Competence of Graduates at the Workplace
}

\author{
(Case Study STEI Alumni Class of 2012)
}

\author{
Muhammad Ramaditya*, Syahrul Effendi \\ Department of Management \\ Sekolah Tinggi Ilmu Ekonomi Indonesia \\ Jakarta, Indonesia \\ *ramaditya@stei.ac.id
}

\begin{abstract}
The purpose of this research is to know the Tracer Study of the alumni profile and STEIs contribution to the competence of its graduates in the world of work (case study on the 2012 Batch of alumni). This study uses sampling from the data obtained by distributing questionnaires to 2012 alumni for the past 4 months. The method used in cluster analysis finds an optimal grouping of observations or objects in each cluster that is the same, but different from each other. The STEI Tracer Study research report in $\mathbf{2 0 1 2}$ class focuses on research on the target of STEI alumni respondents in the year of 2012. From some of the discussions and data obtained in this study, several conclusions can be drawn regarding the characteristics and profile of the respondent when undergoing lectures, the relationship between universities and work and current job conditions. Based on the characteristics of respondents, the amount of data entered is $\mathbf{3 0 3}$ alumni, with details of 94 men $(31 \%)$ and 209 women $(69 \%)$. Overall STEI 2012 alumni as a whole have an average IP score of 3.11. STEI alumni of the 2012 employment status currently are 251 people working, 5 people working and self-employed, 32 people are not working, and 12 people are entrepreneurs. Overall, STEI was able to increase its contribution and more evenly related to the provision of competencies for students (not only focus on knowledge in related fields, but also soft skill and hard skill factors).
\end{abstract}

Keywords: Tracer study, alumni profile, graduates competencies

\section{INTRODUCTION}

Higher education as the organizer of higher education has a very important role in educating the nation, especially it is expected to produce quality graduates who are ready to work or ready to create jobs in the community. How much higher education graduates can take part in development according to the relevance of their education can be traced to their graduates (tracer study). Tracer Study is a study of graduates of higher education institutions. The results of the Tracer Study will be a reference to assess the quality and quality of education of a tertiary institution. Going forward, this information is used to make meaningful decisions about study designs and practical solutions based on the results [1]. Tracer Study has been carried out by many countries around the world, including Germany, Armenia, the Netherlands, Ethiopia, and Indonesia is no exception. Associated with the world of work, Tracer Study tracks the transition process of a student after graduation until the beginning of his work career 1-3 years after graduation, depending on each cohort. At this stage, students who are already employed and are considered to have enough experience to provide an assessment of the field of work. The results of this assessment are used by universities to determine the level of success of the study design and as a reference for evaluating so they can produce graduates in accordance with work demand.

Education is one of the supporting factors in the progress of a nation. Education must be continuously improved in terms of quality and quantity. However, the high costs required to get an education bench is one of the problems faced by most people who want to continue their education to a higher level, especially those who come from underprivileged families. This makes there is limited access to obtain quality education to Higher Education. At Indonesian College of Economics Jakarta (STEI), students do not merely obtain academic education but also non-academic education. Non-academic education obtained by STEI students is generally obtained by their active participation in organizations that are listed and registered with STEI. This organization is quite many kinds, ranging from sports-based, arts, culture to hobbies and related fields of science. The realization of the organization's activities, of course, alumni are expected to be able to play an active role in the world of work both in their work and in their environment. Active alumni in the organization must also include STEI in order to be able to provide better direction and coordination to organizations that are recorded at STEI.

Tracer study is a study whose main purpose is to obtain information about graduates who are working and not working. Besides tracer study aims to determine the results of education in the form of mastery and acquisition of graduate competencies that are applied in the world of work as well as the transition from the world of higher education to the world of business and industry. Through this tracer study, education 
providers can find out how the implementation and quality of program services through the assessment of alumni [2]. Through this the education provider can improve the quality of its services. Educational output in the form of an assessment of the mastery and acquisition of competencies, the educational process in the form of an evaluation of the learning process and the contribution of higher education to the acquisition of competencies, as well as educational input in the form of further exploration of graduate information [2]. Therefore, this study has the main objectives, namely: (1) to find out the profile of alumni respondents in the class of 2012, (2) To find out the assessment of STEI alumni of class of 2012 on aspects of learning at STEI. (3) To find out the assessment of STEI 2012 alumni of the workforce.

\section{METHOD}

\section{A. Tracer Study}

Tracer study is a study of graduates of institutions of higher education providers [3]. Tracer study is an activity that serves to provide information for the purpose of evaluating the educational outcomes of an institution. From the results of tracer studies, it can be seen how an institution produces graduates by looking at how graduates in the community or in the industrial world. In addition, tracer studies affect the development of human resources through short-term and longterm programs and maintain the quality of graduates that have an individual, institutional and state impact. While the classifies tracer study, including in the continuous descriptive method that is to research descriptively on an object of research [4]. This research is usually carried out in examining social problems.

The main focus of tracer study is to obtain information from graduates who are working or not working, as material for policy making in the context of developing or perfecting an institution. Based on the description above, it can be concluded that the tracer study is a study of graduates of institutions of higher education that aims to provide information about graduates who are already working or not yet working and the assessment of graduates of educational institutions and satisfaction of graduate users regarding the competence of graduates in work.

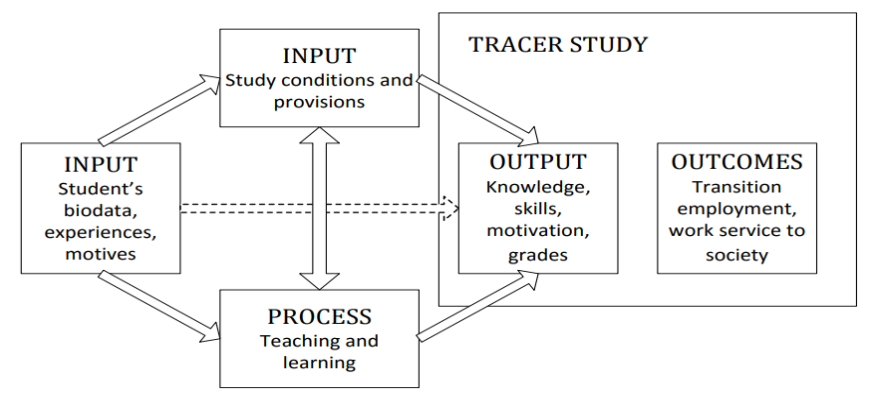

Fig. 1. Basic concept of treasure study.

In accordance with Fig. 1, universities need to carry out Tracer Study because it requires feedback from alumni in their efforts to improve the system and management of education.
The tertiary institution at the beginning of the school year determines the direction of higher education policy in terms of conditions, experience, and motivation of new students entering the college. Enter about the conditions, experience and motivation also determine universities in implementing education systems and management in terms of teaching and learning patterns or processes, research, practicum, workshops, laboratories, studies or research.

\section{B. Benefits of Tracer Study}

The benefits of tracer studies according are (1) as input for improving teaching and learning processes, (2) evaluates the applicable curriculum, lecture materials, the adaptability of graduates in the workplace; and (3) as material to evaluate alumni unemployment rates, find solutions and serve as a tool for forming information networks [5]. Meanwhile, SEARCA states that tracer studies are useful to provide a description of the career movements of an alumni of a tertiary institution, to become an institution's source of data about the condition of students after completing tertiary education, and to predict prospective future rules and potential contributions to the development of a tertiary vision and mission [6]. Based on the description above, tracer study is useful as a source of data for tertiary institutions or educational providers about the condition of students who have graduated and as a means of evaluating tertiary institutions in order to improve, improve the quality of education and services and realize the vision and mission to be achieved.

Several previous studies on Tracer Study have been carried out that the results of the class of 2009 ITB student analysis with scholarship funding sources had a higher GPA as well as a higher level of activity compared to other students [7]. Furthermore, another research shows that large gaps occur in competencies related to interactions such as negotiation and communication skills [8]. Whereas competencies that rely on individual abilities such as analytical skills and independence tend to have a small gap in the 2014-2016 STEI study database tracer. Another tracer study stated that the competencies studied in the hard skills category obtained from the CPI have an average gap that is more positive or better meets the expectations of the interests of business and industry competencies obtained from participation in the organization [9].

\section{Data Collection and Analysis}

In general, the implementation of this tracer study includes the following three steps: (1) development of concepts and instruments; (2) data collection; and (3) data analysis and reporting [10]. This study aims to describe the assessment of alumni of the implementation and quality of service quality programs, assessment of alumni users of the competencies of graduates of the Indonesian College of Economics Jakarta. Population is the whole element or elements to be studied. The population in this study were all STEI students who successfully passed the 2012 class of 303 respondents. Class of 2012 as respondent is the most appropriate choice in 2019 if they pay attention to their graduation year which is in 2-4 years. If someone wants to examine all elements in the research area, the research is a study population or also called a census 
study population. Therefore, the success rate of this study is assessed by how much the response rate is obtained. One of the keys to the success of this Tracer Study research in its efforts to increase the response rate in conducting a Tracer Study lies in the methodology used. The STEI Tracer Study Team used the methodology of the entry of cohort approach as the target respondents [11].

The reason researchers used and developed the entry of cohort approach in determining Tracer Study target respondents include; (1) STEI tries to take advantage of the networking that has been formed in the alumni environment since they entered college, Indonesian people have a culture to share, internet users (social media) in Indonesia are quite high in number, looking for new breakthroughs in the implementation of Tracer Study to overcome the difficulties that arise in increasing response rates [12]. The entry of cohort approach in determining the target of tracer study respondents is basically the same as trying to take advantage of established networking. Networking that has been formed is very helpful, especially in terms of finding the completeness of the database with the help of surveyor intermediaries so that the validation of this database can be close to $100 \%$. Networking that has been formed also helps the performance of the STEI tracer study team when the questionnaire filling process takes place. Only by chatting with friends through surveyors, alumni can fill out questionnaires without coercion.

The first step in implementing the STEI Tracer Study is to make a work plan planning, such as setting the survey objectives, the expected target of the respondent, the length of time of the study, and the technical in conducting survey. In this study carried out by adopting several Core Questionnaire from UNITRACE (International core questionnaire). The next step is gathering the alumni database. The STEI alumni database was obtained from study programs and databases completed by surveyors.

The second phase, which was carried out for three months by the researcher, was a crucial stage in the STEI Tracer Study. If the respondents who fill in the questionnaire are less or even far from the target set, it is very likely that the objectives of the tracer study cannot be achieved properly. At this stage every month a meeting is held between the surveyors and researchers to discuss the technicalities as well as the progress or existing constraints. One key to success in fulfilling the target respondents lies with the surveyors. This is because alumni are more likely to fill out questionnaires when classmates from their majors request it. Email blasts that will be carried out by the STEI Tracer Study Division are scheduled once a month and additional email delivery is done according to surveyor requests. The alumni database is updated as the alumni data collection process runs to completion. The method of approach to respondents is slightly different when entering the third month. Alumni who have not filled out the questionnaire in the third month received an SMS blast in the second, third and fourth week. When making an SMS blast, you should also pay attention to the lag time by implementing the email blast. The sending time of the SMS blast must be different from the time of sending the email blast. Alumni will also be contacted by telephone in the last week if the respondent's target has not been fulfilled. Contact by telephone is based on surveyor recommendations.

Data observations in the tracer study data consist of quantitative and qualitative data. Quantitative data can be classified into nominal and ordinal data, while quantitative data is divided into discrete and continuous data. Nominal data in tracer studies are exemplified by gender, faculty or study program, while ordinal data is often found in the assessment of aspects of teaching and learning in tertiary institutions, assessment of tertiary facilities, activeness of alumni organizations, or competencies possessed by alumni competencies obtained by alumni in tertiary institutions. In the analysis of the main components, cluster analysis and correspondence analysis are part of the multivariate analysis technique, the results of data processing using Microsoft Excel.

\section{RESUlTS AND DiscUSSION}

The research in the STEI Tracer Study categorizes the main work in 4 main categories, namely not working or continuing study, entrepreneurship, work and entrepreneurship, and work. Not working or continuing studies shows alumni who choose not to work or continue their studies to a higher level after graduating from college. Entrepreneurship shows alumni who choose to build their own businesses. Work and entrepreneur show alumni who choose to work while having a side job (generally building their own business).

The total respondents in this tracer study were alumni of the Indonesian Institute of Economics (STEI) class of 2012. Class of 2012 as the respondent was the most appropriate choice if they paid attention to their graduation years at intervals of 1-3 years. After obtaining verification from the STEI Study Tracer Surveyor Team, it involved 303 alumni of the 2012 STEI alumni and 303 alumni had validated email addresses. The Tracer Study was conducted for 3 months, from August to the end of September 2019. During the 3-month STEI Tracer Study, researchers obtained a response rate of 303 respondents.

Total alumni (respondents (who took the questionnaire on the 2012 STEI Tracer Study), if viewed based on gender, the number of respondents with the largest percentage was female (reaching 69\%) and the rest were male (94\%). This shows that women are easier to be cooperative in filling out the query. When seen from the total number of respondents, the Study Program with the most alumni filling out the questionnaire came from the Bachelor of Accounting Program (852 people) and the least filled out the questionnaire came from the Diploma Management Trade Program (23 people). This difference in contribution cannot be compared only with the number of percentages because the number of students per study program was different.
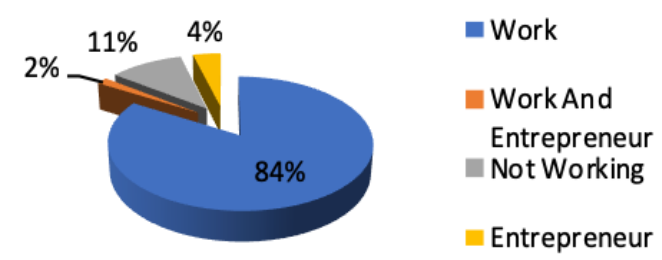

Fig. 2. Work classification class of 2012. 
Based on Fig. 2 STEI alumni class of 2012 have a main occupation, with a total of 256 people. This number shows that most of them chose to work after they graduated from college. However, not all STEI 2012 alumni choose to work after graduating from college. Some of them choose to continue their studies or become entrepreneur. When viewed based on a percentage, STEI alumni of 2012 who chose not to work or continue their studies around $11.6 \%$ and the remaining 12 people were entrepreneurs. The 2012 STEI alumni who decided to build their own businesses when viewed from the percentage were more dominated by alumni from Management Study Programs. While judging by the number of alumni, the alumni who work the most while entrepreneurship come from accounting study programs.

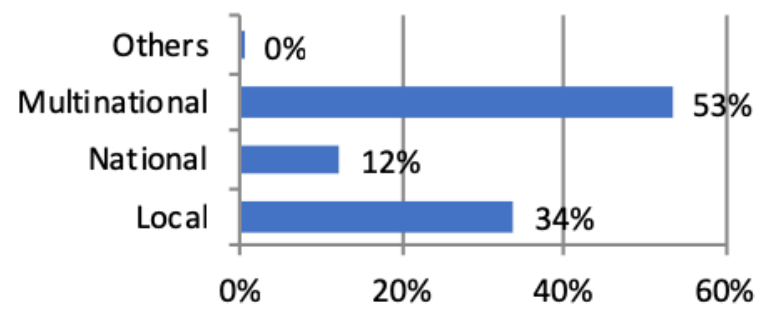

Fig. 3. Company categories class of 2012.

Based on Fig.3, the 303 respondents who worked at the company, there were 251 respondents who answered the category of the company where they worked at this time. The survey results are found that STEI alumni in class of 2012 currently majority worked in multinational companies than national companies. Further analysis of company categories is explained in the classification according to the field of study. Where the majority of jobs are in accordance with the field of study taken in STEI. Out of 251 respondents who worked, around 222 people currently have positions as staff in the company. It is normal, because the Tracer Study was only conducted 1-3 years after graduating from the 2012 STEI alumni, so there are still many alumni who currently do not have very high career paths. But around $8 \%$ have already appointed as supervisory positions and managers. Furthermore, there are $2 \%$ people who are currently apprenticing in the company, so the reason why the apprenticeship position is in great demand today is because some companies currently open an apprenticeship system that makes it easier for college graduates to work before they are accepted into permanent employment.

On the other hand, by looking about income and bonuses, these two aspects are one of the important information that needs to be known from the STEI 2012 alumni who are employed and are entrepreneurs. This information can provide an explanation of the current standard of income and bonuses from fresh graduates. Generally, around 53\% the income of STEI alumni working class of 2012 is equal to or less than $5,000,000$ Rupiah and around $41 \%$ have incomes in the range of 10,000,000 Rupiah This income is quite large compared to alumni who have an entrepreneur turnover in the range of $\mathrm{Rp}$. $8,000,000$ and alumni who work and are entrepreneurs have a turnover of around 10,000,000 Rupiah.
We also found that $53 \%$ of respondents answered the positive things that alumni get in the place where they work is that they get accounting knowledge because of job rotation. The next positive thing is the flexibility. By giving the view that the flexibility given by the company to the alumni in the workplace provides positive things related to work such as working hours, wages, workplaces and others. The next thing that gives a pretty big impact is in personal development. This is because they want to develop themselves in their current main work. It means that the company has been able to provide a place for alumni to learn something new. Then the rest is a conducive and pleasant work environment that has a sizeable portion.

However, every company certainly has its own weaknesses. Negative things related to the work of alumni were also displayed in this tracer study, so that this could be a consideration for companies to correct their shortcomings, so that the company could provide better facilities for its employees. It also explained that the salary which is less satisfying becomes the most negative thing chosen by alumni. Followed by less conducive environment and others such as very small learning opportunities, jobs not in accordance with alumni interests, and uncomfortable locations.

\section{A. Entrepreneur}

Besides working in the company, it turns out that STEI Indonesia 2012 alumni also have an interest in becoming an entrepreneur. The reasons they choose to become entrepreneurs also vary. The main reason they chose the job was because they worked in accordance with their passion or desire, continued family business, had more flexible time compared to working in the company. The next reason is because they can realize their business goals, open new jobs, have a large income, have new challenges and are not dependent.

Seeing quite a lot of alumni who decide to become entrepreneurs, it can be concluded that not a few STEI alumni can open their own businesses. This can be input for the STEI in providing a forum for development for entrepreneurship so that students who want to get involved in the business world already have enough knowledge to start their business since graduating from college or even while they are still in college.

Based on the classification of the fields of business carried out by alumni who have entrepreneurs having various categories. The most widely performed line of business is. Food and beverage provider businesses by $25 \%$. Furthermore, professional service providers, personal services and retail traders, not cars and motorcycles, ranked second with $17 \%$. The rest opened farming, livestock, chemical industry businesses and some respondents did not provide information on the type of business.

\section{B. Job Search}

One of the processes experienced by STEI alumni in living their lives is the transition from the world of education to the world of work. One of the processes undertaken during this transition is regarding job search. Things related to job search some of which are time for job search, determine where the workplace plans are until the process of getting a job. For the 
record, this transition period is not. Valid for all alumni of STEI undergraduate, bearing in mind that some alumni choose not to work or continue their studies after graduating from college.

In the 2012 STEI Tracer Study, things that were the focus of research in the alumni job search process were related to the length of time they looked for work, the media used in finding work and the number of companies that were applied for. The path to getting jobs is sourced from the relations of parents, relatives and others as much as $42 \%$ and $21 \%$ of the internet such as job street, company website and others are $36 \%$ like taking part in job fairs and apprenticeship programs. The intended internal environment or relation is the role of friends or alumni and lecturers and STEI career center, as a unit that provides careers in terms of careers to STEI students and alumni.

\section{CONCLUSION}

Based on current work conditions, the 2012 STEI alumni chose the first job on the grounds of gaining accounting and management knowledge and can be applied to the workplace, flexibility and self-development opportunities. Most of the STEI 2012 alumni who are not working are mostly looking for work or are continuing their studies. STEI 2012 alumni who choose to run a majority business because they can develop themselves, according to their interests, a conducive and pleasant environment. Alumni who run businesses generally have a turnover of 6 rupiah per month for entrepreneurs. STEI alumni of 2012 work more in companies with service activity categories. In terms of the company category, STEI alumni in 2012 worked more in private companies. For alumni positions that work, the majority of STEI alumni in 2012 are still staffed. On the income side, alumni who work generally have an income of 5 million-rupiah, work and entrepreneur 10 million rupiah and entrepreneurship 6 million rupiah. According to the 2012 STEI alumni, a positive picture regarding the work of alumni is Gaining knowledge due to rolling work, Conducive work environment Flexible, Great personal development, and A pleasant friend.

The STEI Tracer Study Research Report on the 2012 alumni also provides input for STEI based on data obtained from the 2012 batch of STEI alumni. Some of these inputs include the contribution of the Study Program, it is expected that each Study Program at STEI will equip more students with entrepreneurial skills. In terms of campus facilities, STEI is expected to build more adequate facilities related to student activity centers since the majority of STEI students (especially 2012) are very active in student activities.

Overall STEI can increase its contribution and more evenly related to the provision of competencies for students (not only focus on knowledge in related fields, but also soft skill and hard skill factors). STEI is better in applying the knowledge of scientific disciplines to the conditions of the business and industry world considering that in this report there are several study programs that have a very small suitability for college and work. Furthermore, STEI is expected to be able to reduce the waiting time gap to get alumni work especially after graduation. Lastly STEI is able to become a better intermediary, especially related to student relations with lecturers and alumni, considering that many STEI graduates get jobs through information from lecturers and alumni themselves.

\section{REFERENCES}

[1] H. Schomburg, "Current Developments of Tracer Studies- International Experieces," International Centre for Higher Education University Kassel, Germany. Plenary Prenesentation at Workshop in Sinaia June 2010.

[2] I. Sailah, Tracer Study Tracker for Higher Education, Jakarta (Director of Learning \& Student Affairs of the Directorate General of Higher Education), 2011.

[3] H. Schomburg, Handout for Graduuate Tracer Studies, 1st ed., vol. 1. Germany: International Centre for Higher Education Research, pp.6873, 2003.

[4] M. Nazir, Research Methodology, 1st ed., vol. 2. Indonesia: Ghalia, 1999.

[5] S.Bambang and M. Ahmad, "Research methodology in communication," Open University, vol. II, pp. 90-100, 2000.

[6] Searca, "Tracer Study on SEARCA Fellows and UC Grantess," Retrieved from ; http://aau.org/studyprogram/web/scholarship. 24 Agustus 2008.

[7] A. Alifah, D. Angga, and S. Bambang, “. Hubungan Sumber Biaya Pendidikan terhadap Prestasi dan Keaktifan (Studi Kasus Tracer Study ITB 2016)," Pasper Tracer Study, pp. 74-75, 2016.

[8] S. Awalia, S. Bambang, and D. Angga, "Gap Antara Kontribusi ITB terhadap Kompetensi lulusannya di Dunia Kerja (Studi Kasus Tracer Study ITB tahun 2014-2016)" Tracer study Paper, pp. 12-15, September 2017.

[9] M. Gunawan, E. Laura, D. Angga, and S. Bambang, "Perkembangan Kepentingan dan Kepuasan Dunia Usaha dan Industri terhadap Kompetensi Lulusan ITB (Studi Kasus Tahun 2010- 2013 dan 20152016)" Paper Tracer Study, 2017.

[10] S. Bambang, D. Angga, N.Faidzatus, and N. Fadilah, "Report Tracer Study ITB angkatan 2008," Penerbit ITB Bandung, vol. 1, 2015.

[11] D. Angga, S. Bambang, M. Samdrp, and Y. Brian, "Pros \& Cons of Target Responden: Between Cohort and Entry of Cohort n ITB Tracer Study, Paper discussion at international conference EXLIMA, 2015.

[12] A. Nursyahabani, S. Bambang, and D. Angga, "How to Increase Response rate; ITB Tracer Study Experience. Poster Session presented at international conference EXLIMA, 2015. 